\title{
Technology Commercialization: Indian University Perspective
}

\author{
Pradeep Srivastava', Sunita Chandra²
}

\begin{abstract}
Technology transfer is the complete, enabling disclosure of advancement in Science and technology, sufficient for its unfettered use and improvement. Universities and institutions of high end research and learning are the focus of such knowledge economy. University- industry partnerships in the field of Science and technology are complex and develop through a large number of mechanisms. The protection and the licensing mechanism of Intellectual property rights at such institutions are the focus of attention of the policy makers at all levels, including the Parliament, wherein a bill has been passed recently, PFIP Bill,2010, which emulates the technology commercialization at US University through Bayh Dole Act. A detailed commercialization process has been evaluated and the success of such technology transfer analysis and commercialization has been reviewed with reference to controlling parameters and revenue being generated.
\end{abstract}

Keywords: technology commercialization; intellectual property rights; bayh dole act; pfip bill; licensing authority.

\footnotetext{
'Associate professor, School of Biochemical engineering Coordinator, TePP, TCFA and Technology Business Incubator, Indian Institute Of Technology, Banaras Hindu University, Varanasi-22 1005, India. Email:drpradeep 19@gmail.com. Ph-0542-6701495,9307I 60605. To whom all correspondance be addresed.

2Deputy Registrar (Adminstration) Banaras Hindu University,Varanasi-221005. Email:sunitachandra_07@yahoo.co.in.

Ph-0542-670I658,2369686.
}

ISSN: 07 I 8-2724. (http://www.jotmi.org)

Journal of Technology Management \& Innovation (C) Universidad Alberto Hurtado, Facultad de Economía y Negocios. 


\section{TECHNOLOGY COMMERCIALIZATION Indian University Perspective}

Universities are knowledge based organizations whose functions are largely confined to teaching and research. They are designed to operate --to discover-- and disseminate knowledge by possessing significant and relevant expertise in all disciplines. India has a very vast structure of education and its higher education sector is now highly advanced, compared to its neighboring countries, (Report of Steering Committee on Science and Technology, GOI, 2006).The importance of technology and science in this decade has been defined explicitly by Jospin, who has concluded that "New product \& and processes will be required to move today's industries in the next century and to achieve industrial competence and sustainable growth, (Jospin, L. 1998).

In this era of knowledge economy, the drivers for the economic growth include the strong base of discovery oriented research in Universities and research institutions. There has been a radical change in institutional priority, towards research and technology development including IP creation, its commercialization and development of funding model that would produce a sustainable, financially self sufficient enterprise. Subsequent to Mashelkar's committee report acceptance, the Centers for high end research have evolved best practice operations which include IP Policy, Licensing procedures and performance evaluation. These institutions are creating adequate expertise in business, legal and IP along with understanding of University culture and a service orientation. There is active engagement from the technology enterprises, creation of Science and technology park and business incubators at these institutions, who do have tacit understanding and deal responsive to early stage VC's and business angels (Albert and Scott, 2003, Inzelt, A. 2004).

Emergence of science-based industries (also termed as "high-tech" industries) has motivated universities to have a more direct role in the innovation process in the High Innovation Economy(HIE). University research and technology transfer has been linked to the needs of local industry for eg. Purdue University controlled the development of locomotive industry, University of Oklahoma, for the development of Petroleum industry and University of Akron contributed to the development to Polymer Industry, (Rosenberg and Nelson, 1994).

The transfer of technology from academic institutions is an important part of the university environment, representing each institution's commitment to improving the public good by promoting the development of its intellectual property into usable products. The efforts have the collateral benefit of promoting economic growth through the creation of companies around academic technologies, job creation, and attendant economic multipliers.
The IP management at the university evolves out of an interaction of three interfaces, including technology management practices, legal aspects and business issues. The technology management includes Research strategy, planning, contract, invention disclosure, patent information and search and technology transfer processes. Whereas, IP and legal aspects includes IP Creation, information dissemination, IP Guidelines, Patent application formulation, IP Policy, legal matters, Licensing and management of License.

The Technology development at Universities and the legal implications of Licensing and commercialization for the growth and development of nation is a proven story. In 1980, the Bayh-Dole Act, in USA, created a uniform patent policy among the many federal agencies funding research, (Bayh Dole Act, PI 96-5 I7, 1980).

\section{BAYH - DOLE ACT}

The findings of research in universities are expected to be filed for patent protection and to ensure commercialization upon licensing. The university must disclose to agency about any new findings within 2 months. The Election of ownership is to be done within 2 years. The Patent is to be filed within a year. The application should indicate government support in patent and provide confirmatory license to US government. The royalties from such ventures are shared with the inventors; a portion is provided to the University and department/college; and the remainder is used to support the technology transfer process.

The reason that the Bayh-Dole act is so instrumental to university technology transfer is that it speeds up the commercialization process of federally funded university research and helps new industries to develop quicker. Examples range from Stanford's Cohen-Boyer patent on the basic gene splicing tools - to the Axel patents, from Columbia University which provided a completely new process for inserting genes into mammalian cells to make protein. Bayh-Dole has also enabled laboratory advances to become a significant factor in U.S. and Canadian industrial growth.

Throughout the post-WTO era, research universities had sought to commercialize in-house innovations, but with the passage of the 1980 Bayh-Dole Act by the American Congress, the effort accelerated dramatically which earlier did not have much experience with private industry or technology transfer.

\section{The Protection and Utilization of Public Funded Intellectual Property Bill, India, 2008 ( PFIP Bill)}

The Science and Technology Policy, of India, 2003 aims to (a) maximize the incentives for generation and protection 
of intellectual property and provide a policy environment for domestic commercialization of such inventions to serve public interest; (b) raise the level of investment in science and technology to at least two per cent of GDP, with the help of industry.

The I I th Five Year Plan stated that an appropriate legislative framework is needed for incentivising the innovators and commercialization of public funded R\&D, where the government, the recipient, the investor and the public benefit from the protection and commercialization of intellectual property.Also, the National Knowledge Commission, chaired by $\mathrm{Dr}$ Sam Pitroda, recommends that a law be enacted to create a uniform legal framework for government funded research and give universities and research institutions ownership and patent rights which would create an enabling environment to commercialize such inventions through licensing arrangements where inventors would also be allowed to receive a share of the royalty.

The Protection and Utilization of Public Funded Intellectual Property Bill, (PFIP) 2008, being passed by Government of India, seeks to provide incentive to create intellectual property and the mechanism for its protection and utilization, ( PRS India media. 2010).

\section{Highlights of the Bill}

- The Protection and Utilization of Public Funded Intellectual Property (PFIP) Bill, 2008 seeks to provide incentives for creating and commercializing intellectual property from public funded research.

- The Bill requires the scientist who creates an intellectual property to immediately inform the research institution. The institution shall disclose this information to the government within 60 days.

- The institution is required to inform the government of the countries in which it proposes to retain the title to the PFIP. The title in all other countries will vest in the government.

- The scientist shall be paid a minimum of 30 per cent of net royalties received from the PFIP.

- $\quad$ Failure of the scientist to intimate the institution and of the institution to inform the government carries penalties, which include fines and recovery of the grant funds.

Globally, the universities and research institutions have been addressing the use of IP creation, management and technology commercialization using legal provisions. The Table I depicts the various laws on public funded intellectual properties in various countries.

\section{TECHNOLOGY COMMERCIALISATION PROCESS}

The transfer of technology from academic institutions is an important part of the university environment, representing each institution's commitment to improving the public good by promoting the development of its intellectual property into usable products. The efforts have the collateral benefit of promoting economic growth through the creation of companies around academic technologies, job creation, and attendant economic multipliers.

The flow sheet below exhibits the whole process.

\section{LICENSING ARRANGEMENTS}

Technology Transfer is a commercial process and it involves a number of activities starting the time when the first communication is addressed to the prospective licensee. The other activities includes preparation of technical note, preparation of provisional patent application, preparation of material samples or prototypes, preparation of comprehensive know how documents etc.

Every innovator suggests the university or research institution regarding its exclusive versus non-exclusive rights. The exclusive rights suggest that the technology may be exclusively licensed to an external agency/ company/ manufacturer; where as the non-exclusive licensing enables the University's Technology Transfer Office, to license out the technology to many agencies as and when needed.The University will license its IP/technologies using multiple options on case-to-case basis through non-exclusive or exclusive licenses, or by entering into joint commercialization agreements. The other important issues to be considered are Field(s) use - geographic and market, the economic terms - royalty, sublicense royalty, performance payments, annual fees and/ore equity. The technology transfer involves the diligence terms - including development and commercial.

The Licensing Agreement would require having dialogue/ negotiations with the parties in respect of contract terms and conditions; royalty/fee to be charged, etc., developing/ executing MOU as per the standard framework reinforced with the mutually agreed terms and other specific conditions, if any. Prior approval of the Competent Authority, may be required for adding/ altering/ deletion of a specific condition in the Agreement, if any:

I. The condition concerns some policy dimension or issue in the interest of the University/ research centers.

2. The contracting party has requested to add/alter/ delete the condition which it considered utmost necessary,

ISSN: 07 I8-2724. (http://www.jotmi.org)

Journal of Technology Management \& Innovation @ Universidad Alberto Hurtado, Facultad de Economía y Negocios. 
1. Applied or basic research generates a new technology or product

3. Invention Information Form

\section{Recognition of potential commercial applicability}

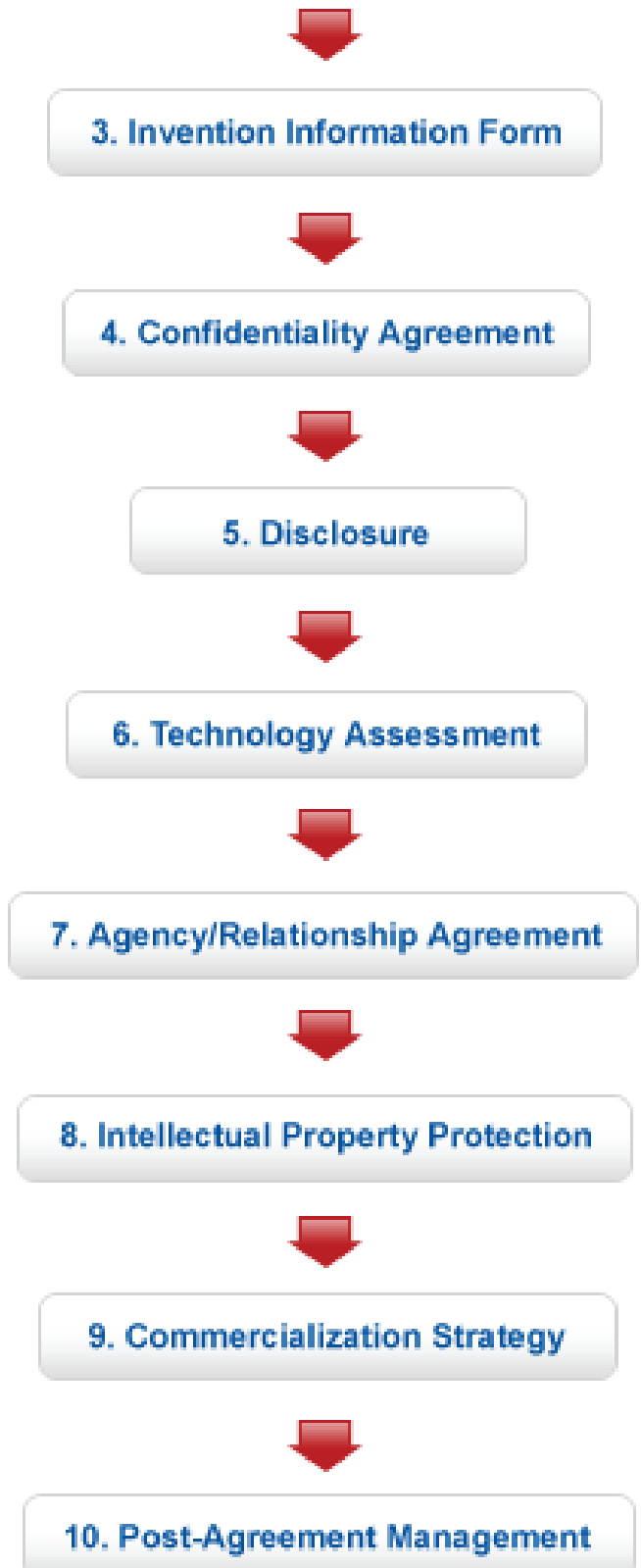


and for which the institution does not have difference of opinion, in principle.

3. It is felt by the institute that some other specific Terms and Conditions have to be added or altered in the Model Terms and Conditions, on which there is mutual agreement with the contracting party.

The following illustrations are made in respect of handling the negotiations, finalization of documents and entering into the contracts/agreements.

- Issues relating to contracting, pricing, payment and ownership of intellectual property will be preadetermined in a Memorandum of Agreement (MOA) signed by the University and the foreign client in cases of exploitation of the University knowledge base by foreign clients for research and/or commercial purposes while safeguarding the interests of the country vis-à-vis the research/professional interests.

- $\quad$ The Terms and Conditions, and Limitations of the Agreement with prospective foreign client will be set / negotiated by the University, preferably with a suitable involvement of Technology Managers/ License Managers or IP Consultants.

The other issues which need regulation and control are Warranties, termination and dispute resolution during the course of technology Licensing and maintenance.

The requirements of various stake holders during technology licensing can be enumerated as below:

\section{Requirements of Faculty}

The Research scientists and faculty at the Indian universities look towards the following:

- $\quad$ An alternative approach to create professional and societal impact beyond instruction and publication

- Minimal intrusion into direction of basic research and ability to publish results

- Experiences that produce competitive advantage to attract the best students and research support

- $\quad$ Sources of funds that are not otherwise available discretionary research and personal funds

- Opportunities to participate in development and commercialization

\section{Requirements of University}

The University would try to achieve :

- $\quad$ A true commitment to further develop and eventually commercialize the technology.

- An understanding of university values and constraints, e.g., publication and Suitable regulations and Acts

- A fair price, uncomplicated royalty terms and an opportunity to share in the upside.

- $\quad$ Reasonable terms for acquiring new IP

- A role for the faculty inventor

- $\quad$ To retrieve the IP if licensee doesn't produce.

Licensing Arrangement and Process therein requires certain evaluations and assessments which are:

\section{a. Technical feasibility:}

The technical feasibility of the proposed technology to be transferred should attempt to define the technical asset, the requirements for the production and product infrastructure working. Its up-scaling to the size necessary for economic success and the technical alternatives, their IP, economic and market implications relative to the subject IP. What is the product and How long will it take to develop and at what cost?

\section{b. Commercial potential:}

The commercial potential of the patent needs to be well defined, so that this can evaluate how a licensee make money from this IP.

There should be understanding of the sense of the product and the context in which it could be used. The other issues which need to be considered are:

I. Whether it's a continuous innovation or discontinuous innovation.

2. What is the value proposition for the product replacement and benefit economics?

3. Some call this the "pain threshold", what pain will it cause a competitor and relief to a user?

4. How does one extract the economic value for the pain/benefit, i.e., what are the transaction points where value is attributed and exchanged?

\section{c. Discount factors:}

During the process of defining the cost of the Technology and its sublicensing discount factors play an important role. This may be summarized as below: 


\begin{tabular}{|lll}
\hline Risk level & \multicolumn{2}{l}{ Discount rate $\quad$ Description } \\
Nearly Risk Free & $10-18$ & Existing product \\
Very low risk & $15-20$ & Improved existing product \\
Low risk & $20-30$ & New product, wu technology, existing market \\
Moderate risk & $25-35$ & Same as above with competition \\
High risk & $30-40$ & New product, nwu technology, existing market \\
Very high risk & $35-45$ & New product, new technology, new market \\
Extremely high & $50-70$ & New company, unproven technology, new market
\end{tabular}

\section{d. Product lifecycle:}

If any research outcome ends in a product, which has a commercial entity, it can be further commercialized through a process. The total profitability analysis can be predicted as given in Fig I.

The cash flow generated with reference to research expenses and time exhibits sufficient high earnings only after the maturity of the product. The profit also increases with time only after maturity in the market.

Licensee would like to neglect research costs and risk, and emphasize development cost and risk solution is to analyze mature operation, if consider development costs, then amortize over the product life,( Allen David, 2003).

\section{e. Exits}

The technology commercialization process of any institution should address exits of Licensee. In case of any future differences in opinion in Technology Licensing and adoption, there has to be well defined mechanism for exits of such agreements with suitable compensation. However, there has to be difference between exit and termination.

The Termination of a license may be under following circumstances:

\footnotetext{
- At will by licensee, upon breach by licensor

- Breach terms and cure periods

- Treatment of sublicenses
}

There should be also monetization of license asset at the Technology transfer office of the university. But it should address, Why, how, and who as well. The University may define Equity as partial consideration for a license with references to Common v. preferred stock, Member shares in an LLC, its further dilution and liquidation.

\section{TECHNOLOGY COMMERCIALIZATION POLICY INITIATIVES IN INDIA}

\section{Structuring Industry-academia relationships}

In the emerging policy environment with its inherent challenges, there is a growing real isation on part of the academic and research community to collaborate more with industry, leaving aside the differences posed by culture and priorities.

In India, academic consulting has been always a back seat. However, in the absence of a formal legal framework for technology transfer at national level and institution level, there has been no proactive initiative from the research institution end to woo industry. Industry occasionally approaches academics at research institutions for consulting. Relationships between private sector and research institutions are formalized through memoranda of understanding (MOUs), with no guidelines on IP ownership and transfer. Any knowledge generated in consultancy projects accrues to the private company sponsoring the project. On the part of the public sector research system, IP management has not been considered a fundamental component of the overall project management, and not much thought has been given to priority research setting.

Over the past three years, much thought has been given to IP management in the public

research system. This increased awareness has led to development of institutional IPR policies and guidelines at the key national research organizations - CSIR, ICMR, ICAR - and at key academic institutions such as the Indian Institutes of Technology (IITs) in Bombay and Delhi and the Indian Institute of Science (IISc),Bengaluru.

The IP policies at IISc Bangalore and IIT Bombay have detailed guidelines on extra mural consulting and have sections devoted to conflict of interest.

To promote entrepreneurship at the institution level, IISc Bangalore and IIT Bombay have set up umbrella organizations. At IISc, the Society for Innovative Development (SID) is a forum that supports its faculty and students to incubate their technology ventures. The Society for Innovation and

ISSN: 07 I8-2724. (http://www.jotmi.org) 
Entrepreneurship (SINE), hosted by IIT Bombay, promotes entrepreneurship at the institute through a business incubator that provides support for technology based entrepreneurship.

At IIT Delhi, the Foundation for Innovation and Technology Transfer (FITT) is engaged in commercializing IP emanating from academic and student research. Between January and July 2008, 17 patent applications were filed by academics through the FITT, (Kumar and Jain, 200I)

Some of the recent initiatives in India to facilitate greater academia-industry partnerships are elucidated below:

\section{a. New Millennium India Technology Leadership Initiative (NMITLI)}

This is one of the largest public-private partnerships in R\&D in India, started by the Government of India, and monitored through the CSIR. NMILTI seeks to discover and harmonize the strengths of publicly funded R\&D institutions, academia and industry, and through this process, catalyze scientific and technological innovation in some selected niche theme areas. From 2000 to date, NMITLI has funded 42 projects with an outlay of INR 3000 million, involving 222 public-funded academic and R\&D institutions, and 65 private sector companies. The projects have primarily centered on biotechnology; drugs and pharmaceuticals; and chemicals, (Prabhu Ram, 2008).

One of the success stories of NIMTLI is the development of LLL-3348 (Desoris), a proposed oral treatment of moderate to severe chronic stable plaque-type psoriasis by Lupin Labs, a pharmaceutical company in collaboration with a national R\&D lab, Central Drug Research Institute (CDRI) based at Lucknow and an academic institution, National Institute of Pharmaceutical Education and Research (NIPER), at Chandigarh. Desoris is currently under clinical trials.

\section{b. The Small Business Innovation Research Initiative (SBIRI)}

The SBIRI is a scheme initiated by the Department of Biotechnology in 2005 to generate ideas through a unique process involving technology producers and users with the aim of generating products that could only be produced with the help of the private sector. The SBIRI scheme is modeled on the lines of the Small Business Innovation Research (SBIR) grants of the US that fund small business development of biomedical discoveries. Timely product development is the sole undeviating goal under this scheme, and this is facilitated through the active engagement of the private sector with the projects of the partnering research institutions.
The projects under the SBIRI cover all sectors of biotechnology, namely medical, agriculture, food, industrial and environmental, and bio medical devices and instruments.

From the time of its inception, the scheme has received a total of 398 proposals from around 250 private sector companies. Of the 398 proposals, nearly $75 \%$ can be categorized as early stage research (phase I); $20 \%$ of the proposals are for scale-up and late development of research leads in the phase II category; $5 \%$ of the proposals are a combination of early stage research and scaling-up. Approximately 155 projects are collaborative in nature involving two or more partners from public R\&D institutions, (shalini Gupta, 2008).

\section{c. National Agricultural Innovation Project (NAIP)}

The Government of India launched the NAIP, with support from the World Bank. This is a 6 year programme, initiated in 2006 and slated for completion in June 2012. NAIP is being implemented by the ICAR with an aim to accelerate the collaborative development and application of agricultural innovations between The NAIP builds on the success of its precursor, the National Agricultural Technology Project (NATP). The NAIP accords high priority to the generation and transfer of innovative agricultural technologies.

A key novel feature of NAIP is its use of competitive funds to establish consortia of research, enterprise and developmental organizations on selected themes, with actors engaged in all stages of a value chain, from supply of inputs to harvesting of a particular commodity.

\section{Encouraging research at public institutions}

Over the past many years, there has been a recognition that India needs to enact a legislation that supports science commercialization. India is currently taking steps to formulate a policy act on the lines of the US Bayh- Dole Act.A draft bill, Public Funded R\&D (Protection, Utilization and Regulation of Intellectual Property) Bill has been approved by the parliament and is under process of bill formulation.

\section{Facilitating Knowledge Transfers in India}

In 2005, CSIR, ICAR, ICMR and DBT established a forum to engage in critical dialogue on technology transfer. The Society for Technology Management (STEM) has, over the past three years, seen more than 100 new members joining it. Apart from the Indian public research system, STEM today includes membership from public research systems from South-East Asia and the Middle East. It also includes membership from leading life science companies in the United States, Europe and India. 


\section{Creation of Technology Business Incubators:}

The ministry of Science and Technology has undertaken the task of Entrepreneurs generation and support, through $\mathrm{Na}$ tional Science and Technology Entrepreneurship Development Board (NSTEDB), where in Creation of Technology Business incubators and Technology Parks is being done in Technology Institutions of repute. To name TBI has been created at IIT, Delhi, IIT Chennai, IIT Mumbai, IIT Kanpur, Delhi University and IT, BHU,Varanasi, ( NSTEDB, 2009). Recently, a Task force of Prime Minister's Office, Govt of India, 2010, has recommended that about $100 \mathrm{TBI}$ be created at $\mathrm{Na}$ tional Institutes of research in science and Technology.

\section{OUTCOME OF TECHNOLOGY COMMERCIALI- ZATION:}

There is no doubt that university technology transfer and commercialization activities are impacting local, state, and national economies. Stanford University has alone filed more than 300 patents and some familiar companies such as Google, Sun Microsystems, Silicon Graphics, Netscape, Cisco Systems, and Yahoo have spun off from the University.Approximately 150 new MIT- related companies are founded each year, with at least 10 percent of those directly resulting from university technology transfer activities. Other University such as Washington University in St. Louis, Georgia Institute of Technology in Atlanta, University of Wisconsin in Madison, and Carnegie Mellon University in Pittsburgh also are making impressive strides and contributing to the diversification and growth of their regional economies, (Shane $\mathrm{S}, 2002)$. The research outcome with reference to the cost input at US universities has been explicitly defined in Table 2.( Everett Rogers, et al, 2006)

\section{SCENARIO at INDIAN UNIVERSITY}

In 2010-20II, the Council for Scientific and Industrial Research (CSIR) has a $21 \%$ share of the total patents granted to Indians - with 454 total Patent License deals. CSIR had disclosed that it had I,872 active patents in India. This means that 400 out of I,872 patents have been licensed i.e. $21.3 \%$ of patents are commercialized. These patents cover abroad spectrum - from drugs to traditional medicine to aerospace engineering. Some ofthe CSIR institutions were successful in transferring the technologies to the private sector.The Central Food Technology Research Institute (CFTRI), Mysore, has been a pioneer in technology commercialization. In other CSIR institutions, the success has been pretty low, with occasional success stories emerging. Some of the licensees include Cadila Pharmaceuticals, Nicholas Piramal, General Electric, Nostrum Pharmaceuticals, DRDO, HAL, AssigneeSignal Stop LLC, USV Ltd., Pepsi, Cocoa-Cola, NMDC. Rajasthan Mines \& Minerals Ltd., Tata Chemicals, Ranbaxy, Shreya Life Sciences, Emcure Pharmaceuticals.
In 2006, the Indian Council for Agricultural Research (ICAR) adopted a new technology transfer/ commercialization policy and guidelines to support the same. As part of the new policy framework, ICAR has established Institute Level Technology Management Units (ITMC) and Zonal Institute Technology Management Committees (ZTMC) to identify and nurture innovations at the grassroots level. Over the past three years, the focus has been on con ducting sensitization workshops for selected scientists. It is too early to talk about successful technology commercialization stories in ICAR, except for the animal vaccines.

The Indian Council for Medical Research (ICMR) and the Department of Biotechnology (DBT) have technology commercialization policies in place, and some success in transferring technologies. In 2006, ICMR reported 46 technologies for commercialization by the private sector. The partnerships with Therion Biologics and Shantha Biotechnics have already been recognized as case studies for encouraging innovative collaborations with the private sector. The patent cell within the DBT has facilitated more than 100 Indian and foreign patents, of which 12 have now been granted, (www. dbtindia.nic.in)

\section{RECOMMENDATIONS:}

Looking into the wide perspective of technology commercialization in Indian University the salient recommendations for a successful technology transfer and its commercialization may be summarized as below:

- A Strong and Focused University Research Base Feeding products in the Pipeline for Commercialization

- Suitable Government R\&D funding, Provides a Critical Base for Technology transfer and Commercialization Efforts

- Champions Catalyze Most Successful Technology which are the basis for Economic Development

- Private Corporations and Foundations Can Play a Major Role

- Early - Stage Capital is a Critical Ingredient in Launching University Start-Ups

- Innovation Centers at Institutions Can Provide a

Focal Point for Technology- Based Activities

- The Entrepreneurial Culture of a University is Key to its Technology Transfer Success

- Networking is Key to Technology based startups and technology commercialization therein

- Entrepreneurship Programs Can AddValue to Technology transfer Efforts

- Incubators and Research Parks Provide a Visible Technology Presence

- No Quick Fixes exist in the economy transition

ISSN: 07 I 8-2724. (http://www.jotmi.org)

Journal of Technology Management \& Innovation (c) Universidad Alberto Hurtado, Facultad de Economía y Negocios. 


\section{CONCLUSIONS:}

University technology transfer and commercialization are complex processes. They involve licensing inventions or starting up enterprises based on the university's research. Research and development (R\&D) resources, infrastructure, seed capital, entrepreneurial incentives and culture, University - industry enablers, intermediary facilitators, and leadership - political, academic and corporate - are just some of the inputs involved in shaping effective processes. The efforts have the collateral benefit of promoting economic growth through the creation of companies around academic technologies, job creation, and attendant economic multipliers.

Although the American technology commercialization model is being widely emulated, by many countries, even in India, some data suggests this may be misguiding. Moreover, a successful practice in one environment may not be a successful practice in another since resources, cultures, environments and priorities vary from university to University, community to community, and state to state. Instead of simply trying to recreate Silicon Valley, there should be explorations, for other models available for technology commercialization that may be more appropriate for the unique context of each country? In what innovative ways are other countries stimulating technology commercialization? The Development and commercialization of new technologies will prove to be an activity of focal attention and a force to reckon with. Indian University to my understanding would be playing an important role in Knowledge economy.

\section{REFERENCES:}

Albert N Link and John T Scott, US Science Parks: the diffusion of an innovation and its effect on the academic mission of Universities, International Journal of Industrial Organization, 2 I (2003), I 323-I 356

BAyh Dole Act, (PL 96-5 I7), Patent and Trademark amendment act of 1980, USA.

Everett M Rogers, Jing Yin and Joern Hoffman, Assessing the Effectiveness of Technology Transfer Offices at US Universities, AUTM, Journal, XII, 2006

Inzelt A.: The evolution of university-industry-government relationships during transition, Research Policy, (2004), Vol. 33, pp. $975-995$

Jospin. L., Towards the factory of next century, In: Innovation and Technology Transfer. European Commission, Luxembourg, January 1998, pp. |6-2|

Kumar, V., Jain, P., Commercialization of new technologies in India: an empirical study of perceptions of technology institutions, Technovation, (200I), 4.I.0, pp.I-8

Prabhu Ram, Tech transfer in the Indian Public research System, Research Global, pp 10-12, Oct 2008

www.prsindia.org/uploads/media// 229425658/LB_protection

Rosenberg, N., Nelson, R., 1994. American universities and technical advance in industry. Res. Policy, 23, 323-348.

Report of the Steering Committee on Science and Technology, for I I th Five Year Plan( 2007-2012), Planning Commission, Govt of India, Dec, 2006

Shalini Gupta, SBRI funded companies taking Wings, Biospectrum India, June, 2008, www. biospectrumindia. ciol.com/ content/coverstory.

Shane, S., University technology transfer to entrepreneurial companies, Journal of Business Venturing, (2002), I7, pp. I- 16

Status Report on Technology Business Incubation in India 2009, NSTEDB, DST, New Delhi

www.dbtindia.nic.in 


\begin{tabular}{|c|c|c|}
\hline Country & $\begin{array}{l}\text { Policies (Name of the } \\
\text { Act) }\end{array}$ & Brief of the Act \\
\hline USA & Bayh Dole Act & $\begin{array}{l}\text { Universities and government funding agencies enter into a funding } \\
\text { agreement which grants a right of ownership to the recipient subject } \\
\text { to a number of obligations concerning disclosure of the invention, } \\
\text { retention of title, royalty sharing and preference to small businesses } \\
\text { and US industry. } \\
\text { The university can retain title and commercialize invention if it com- } \\
\text { plies with the obligations. The government will retain some minimum } \\
\text { rights, including a non-exclusive irrevocable licence to use the inven- } \\
\text { tion, in special circumstances. }\end{array}$ \\
\hline Australia & & $\begin{array}{l}\text { Universities and government research organisations can claim owner- } \\
\text { ship of inventions created by academic staff during their employment, } \\
\text { both under common law and university IP policies and statutes. }\end{array}$ \\
\hline UK & Patents Act, I 977 & $\begin{array}{l}\text { The law provides that an invention made by an employee in the course } \\
\text { of his normal duties shall be taken to belong to his employer. This } \\
\text { provision can, be overridden by a university IP policy and employment } \\
\text { contracts. }\end{array}$ \\
\hline Brazil & 2004 Innovation Law & $\begin{array}{l}\text { Public research institutes are permitted to share their laboratory } \\
\text { facilities with private-sector enterprises. Public research institutes and } \\
\text { private-sector enterprises are permitted to enter into capital relation- } \\
\text { ships for the purpose of R\&D. Public and private partners may specify } \\
\text { the ownership of any future intellectual property rights by contract. } \\
\text { Public research institutes and their employees must protect trade } \\
\text { secrets associated with their research. Public research institutes may } \\
\text { license their technologies to private enterprises. }\end{array}$ \\
\hline Japan & $\begin{array}{l}\text { Article } 30 \text { of The Indus- } \\
\text { trial Revitalization Law }\end{array}$ & $\begin{array}{l}\text { The Act aims to encourage research activities and promote the utiliza- } \\
\text { tion of inventions arising from research or development supported } \\
\text { by the Japanese government. The Act covers patent eligible subject } \\
\text { matters and other subject matters protected by other intellectual } \\
\text { property rights. It aims to share the ownership to the University and } \\
\text { innovator. }\end{array}$ \\
\hline India & $\begin{array}{l}\text { The Protection and Uti- } \\
\text { lization of Public Funded } \\
\text { Intellectual Property Bill, } \\
2008\end{array}$ & \\
\hline
\end{tabular}

Table I: Laws on Public Funded Intellectual Property in other Countries

\begin{tabular}{|l|l|l|l|}
\hline US University & Research expenditures & Research Revenue in 2006 & Yield \% \\
\hline New York University & $\$ 210$ million & $\$ 157$ million & 75 \\
\hline Ohio University & $\$ 24$ million & $\$ 3.26$ million & 13 \\
\hline University of Rochester & $\$ 355$ million & $\$ 38$ million & $\mathrm{II}$ \\
\hline University of Minnesota & $\$ 596$ million & $\$ 56$ million & 9.4 \\
\hline University of Florida & $\$ 459$ million & $\$ 42.9$ million & 9.3 \\
\hline Stanford University & $\$ 699$ million & $\$ 61.3$ million & 8.7 \\
\hline University of Massachusetts & $\$ 409.9$ million & $\$ 27.2$ million & 6.7 \\
\hline University of Utah & $\$ 246.5$ million & $\$ 16.3$ million & 6.6 \\
\hline $\begin{array}{l}\text { University of California } \\
\text { System }\end{array}$ & $\$ 3.04$ billion & $\$ 193.4$ billion & 6.4 \\
\hline University of South Alabama & $\$ 20.6$ million & $\$ 1.2$ million & 5.9 \\
\hline
\end{tabular}

Table 2: Some US Universities That Turn Research into Revenue, in 2006

ISSN: 07 I8-2724. (http://www.jotmi.org)

Journal of Technology Management \& Innovation (C) Universidad Alberto Hurtado, Facultad de Economía y Negocios. 


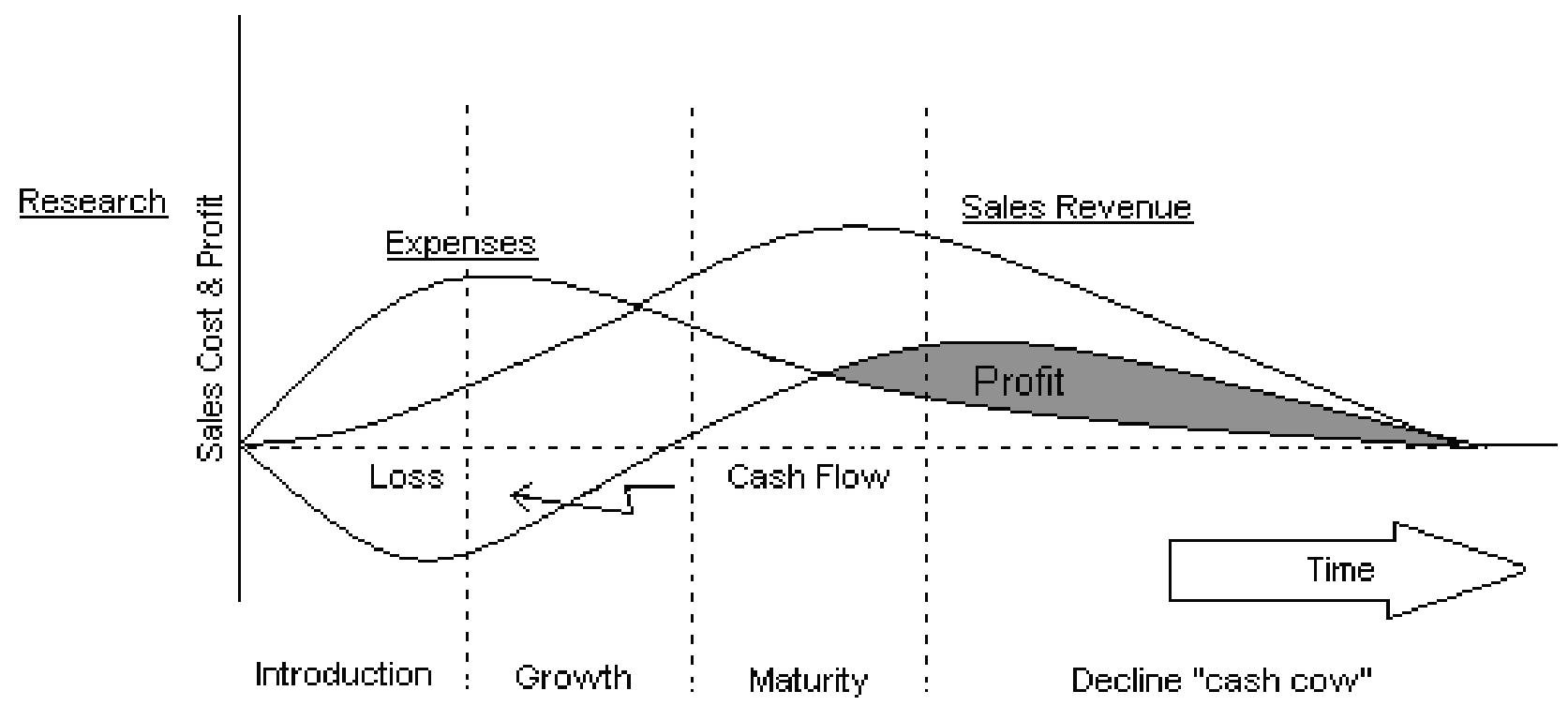

FIG. I: Product Lifecycle 